\title{
Vitamin-Like Supplementation in Dairy Ruminants: The Case of Choline
}

\author{
Luciano Pinotti
}

Additional information is available at the end of the chapter

http://dx.doi.org/10.5772/50770

\section{Introduction}

Recent developments in nutrition have established that choline is an essential nutrient for mammals when a sufficient supply in methionine and folates are not available in the diet. Vitamin B12 is also involved in this process. The dynamic interactions between these components introduced the concept of choline as vitamin-like compound. Two types of choline functions are known: as choline per se, for which the choline moiety is required, and functions as a methyl donor. Choline per se plays a major role in lipid metabolism, particularly in lipid transport, as lipotropic agent. Choline is also an important source of labile methyl groups for the biosynthesis of other methylated compounds. Based on this second function choline and methionine are interchangeable, as sources of methyl groups. Accordingly choline occupies a key position between energy and protein metabolism in mammals.

Choline and methyl group metabolism in ruminants however are different. In adult ruminants, choline is extensively degraded in the rumen; for this reason dietary choline contributes insignificantly to the choline body pool and methyl group metabolism is generally conservative with a relatively low rate of methyl catabolism and an elevated rate of de novo synthesis of methyl groups via the tetrahydrofolate (THF) system. This can be exacerbated in lactating dairy ruminant, in which the dietary availability of choline is nearly non-existent, but the output of methylated compounds in milk is high, while methionine as well as other sources of methyl groups are likely to be in short supply, especially at the onset of lactation. In light of this, the hypothesis that choline can be a limiting nutrient for milk production has been formulated and tested in several studies. Accordingly this chapter will focus on the effects of rumen-protected choline (RPC) supplementation to transition and early lactating dairy ruminants (cows and goats) on milk production and on metabolic health. Experimental data will be discussed in a systematic analysis, in order to define possible recommendations for high yielding dairy ruminants. 


\section{What is choline?}

In 1849 Adolph Strecker, a German chemist, isolated a compound from pig bile, to which he subsequently (in 1862) applied the name choline (from the Greeke, chole, bile). In 1867, Bayer, determined the chemical structure of choline (McDowell, 1989).

Choline is a beta-hydroxyethyltrimethylammonium hydroxide (figure 1), which is widely distributed in nature as free choline, acetylcholine, and more complex phospholipids and their metabolic intermediates. Its role in the body is complex. It is needed for neurotransmitter synthesis (acetylcholine), cell-membrane signaling (phospholipids), lipid transport (lipoproteins), and methyl-group metabolism (homocysteine reduction) (Zeisel \& Da Costa, 2009).<smiles>C[N+](C)(C)CCO</smiles><smiles>CC(=O)OCC[N+](C)(C)C</smiles>

Acetylcholine<smiles>[R]C(=O)CC1CO[P+](=O)OCC1C([R])=O</smiles>

Phosphatidylcholine

Figure 1. Structural formula for free choline, acetylcholine, and phosphatidylcholine (lecithin). R and R' refers to any fatty acids (adapted from McDowell, 1989).

\subsection{Vitamin or not?}

In mammals choline has been classified as one of the B-complex vitamins but it does not satisfy the standard definition of a vitamin (Pinotti et al., 2002): it is synthesised endogenously and there is no evidence that it is an enzyme co-factor; furthermore, unlike other water-soluble vitamins, it is difficult to identify a deficiency syndrome for choline in 
healthy mammals because of its interrelation with methionine, folic acid, and vitamin B12 (Scott, 1999; Zeisel, 1988). Finally, choline is a vital component of tissues and is required in the diet of non-ruminant species at much higher levels than the water-soluble vitamins ( $\mathrm{g}$ vs. mg) (Whitehead \& Portsmouth, 1989). However, the presence of an endogenous synthetic pathway does not render choline dispensable and deficiency results in several dysfunctions when other nutrients are limiting (Zeisel et al., 1991). For this reason it has been suggested that choline may be an essential nutrient (or vitamin like compound) for mammals when excess methionine and folic acid are not available in the diet (Zeisel \& Da Costa, 2009). Consequently choline was officially recognized as an essential nutrient for humans by the Institute of Medicine in 1998 (Food and Nutrition Board, 1998).

\subsection{How requirement for choline can be met}

The metabolic need for choline can be met in two ways: either by dietary choline and via de novo biosynthesis through the methylation of phosphatidylethanolamine to phosphatidylcholine. From the point of view of animal nutrition, relatively rich sources of choline are soybean, soybean meal, rapeseed meal, fish meal and dried yeast, even though its bioavailability is considered "moderate" (Pinotti et al., 2002; Whitehead \& Portsmouth, 1989). Dietary choline from a variety of choline-containing feed and food is absorbed by the intestine and uptake is mediated by choline transporters nutrient (McDowell, 1989). De novo synthesis of choline occurs by the sequential methylation of phosphatidylethanolamine, the methyl groups being supplied by S-adenosyl-L-methionine (SAM) (Mato et al., 1994). However, de novo synthesis of choline alone is not sufficient or rapid enough to satisfy all the animal's need. Methyl groups needed in this pathway may be derived from exogenous sources such as methionine, and betaine but can arise de novo in the body from the tetrahydrofolate (THF) system (Zeisel, 1988; Zeisel, 1992); vitamin B12 is involved in this process (Kennedy et al., 1995). Thus, dietary factors such us methionine, betaine, myoinositol, folic acid, and vitamin B12 or combination of different levels of fat, carbohydrates, and protein in the diet, as well as the physiological state, all have influence on the "requirements" of choline (McDowell, 1989; Zeisel \& Da Costa, 2009).

\subsection{Functions of choline}

Choline is considered a vitamin-like compound with two main functions: as choline per se, for which the choline moiety is required, and as methyl donor, although the two roles overlap.

Choline per se is an essential constituent of all cell membranes, where it is required to make the phospholipids phosphatidylcholine, lysophosphatidylcholine, choline plasmalogen, and sphingomyelin. Phosphatidylcholine, one of the most abundant phospholipids in higher plants and animals, is the predominant phospholipid $(>50 \%)$ in most mammalian cell membranes (Kuksis \& Mookerjea, 1978; Ruiz et al., 1983; Zeisel, 1988; Zeisel, 1992). Choline per se plays a major role in lipid metabolism, particularly in lipid transport, as lipotropic agent because of its ability to prevent or correct excess fat deposition in the liver generally arising as a result of its dietary deficiency (Kuksis \& Mookerjea, 1978; Zeisel, 1988). Impaired triglyceride secretion to very low density lipoproteins (VLDL) is considered a major cause of fatty liver in dietary choline deficiency (Zeisel, 1988). In this context, it is noteworthy that 
bovine VLDL phospholipids are mainly phosphatidylcholine, with smaller proportions of sphingomyelin and phosphatidylethanolamine (Moore \& Christie, 1981). Thus, when massive mobilisation of fatty acids - as at the onset of lactation in dairy ruminants- is associated with lipotropic factor deficiency (e.g. choline) triglycerides accumulate in the liver and may lead to the development of fatty liver (Gruffat et al., 1996). Choline per se is required to prevent hemorrhagic kidney lesions in rats (Kuksis \& Mookerjea, 1978); and together with other nutrients particularly manganese salts, is required to prevent perosis, a bone disease of poultry (Ruiz et al., 1983). In the prevention of perosis, choline is needed as constituent of phospholipids required for normal maturation of the cartilage matrix of the bone, whereas in the prevention of hemorrhagic kidney lesions choline seems involved in the renal phospholipids turnover (Kuksis \& Mookerjea, 1978).

Choline per se is also essential for the synthesis of the neurotransmitter acetylcholine (Kuksis \& Mookerjea, 1978; Zeisel, 1988). It plays important roles in brain and memory development in the fetus and appears to decrease the risk of the development of neural tube defects (Zeisel \& Da Costa, 2009).

As methyl donor, choline, like methionine, is an important source of labile methyl groups for biosynthesis. Actually, the two principal methyl donors in animal metabolism are betaine, a choline metabolite, and S-adenosyl-L-methionine (SAM) a metabolite of methionine (Pinotti et al., 2002 for references). At least 50 SAM-dependent reactions have been identified in mammals, and it is likely that the number is much higher. Such methylation reactions play major roles in biosynthesis of lipids, the regulation of several metabolic pathways, and detoxification in the body (Zeisel \& Da Costa, 2009). Accordingly it has been suggested that choline, and methionine are closely interrelated metabolically (Mato et al., 1994); it is also clear that choline has only little capacity to reduce the requirement for methionine, even though choline seems important to spare methionine as a methyl donor.

Although the choline-methionine interrelationship has been studied extensively (see Pinotti et al, 2002 for reference), less emphasis has been placed on the link between choline and its oxidation product, betaine. Betaine serves as an osmoregulator and is a substrate in the betaine-homocysteine ( $\mathrm{HCy}$ ) methyltransferase reaction, which links choline and betaine to the folate-dependent one-carbon metabolism (Kempson \& Montrose, 2004; Ueland, 2011). The availability of choline and its metabolite betaine appear to influence the conversion or recycling of the HCy moiety of methionine, through betaine-HCy methyltransferase activity (Stipanuk, 1986). However, betaine fails to prevent fatty livers and haemorrhagic kidney (McDowell, 1989), indicating that the requirement for choline per se must be met as choline, and that betaine can substitute only the methyl donor function of choline, probably because betaine cannot be reduced to choline (Zeisel, 1988). Thus, choline per se must provide at least $50 \%$ of the total choline requirement, while the remaining portion of the choline requirement can be replaced by betaine (Dilger et al., 2007).

\section{Choline in ruminants}

Ruminants differ from most other mammals in regard to their choline and methyl group metabolism. In adult ruminants, choline is extensively degraded in the rumen. Quantitative 
studies in sheep showed that $76 \%$ of [14C]-choline injected into the rumen was expired as methane over $6 \mathrm{~h}$, whereas approximately $15 \%$ accumulated as trimethylamine. Under such conditions, less than $10 \%$ of choline escapes degradation by incorporation, as phosphatidylcholine, into the structural membranes of ciliate protozoa (Neill et al., 1979). Nevertheless, the concentration of phosphatidylcholine in ruminal digesta was higher than in abomasal digesta, suggesting that protozoa are selectively retained in the rumen (Neill et al., 1979). In sheep with a defaunated rumen, the concentration of phosphatidylcholine in the abomasal digesta was higher than in the rumen (Dawson et al., 1981), leading to the suggestion that some of this abomasal Phosphatidylcholine was derived from non-dietary sources (regurgitation of bile from the lower digestive tract) (Robinson et al., 1984). In fact, intravenous injection of labelled choline in sheep indicated that the small amount of phosphatidylcholine present in abomasal digesta is largely $(69 \%)$ of non-dietary or ruminal origin (Dawson et al., 1981).

The physiological state however, is important (Table 1). In the pre-ruminant lamb the activities of liver Cho-oxidase and betaine-HCy methyltransferase increase markedly after birth, but subsequently decrease as the animals reach the ruminant state (Xue \& Snoswell, 1986a). The increasing activities of liver choline oxidase and betaine-HCy methyltransferase in pre-ruminant lambs are probably related to the abundance of choline-containing compounds in the milk (Xue \& Snoswell, 1986a- Figure 2). By contrast, in adult ruminants only small quantities of methyl group nutrients are available from the diet and methionine synthase assumes a much more important role (Dawson et al., 1981; Neill at al., 1978; Neill et al., 1979; Kennedy et al., 1995). Methionine synthase is responsible for the de novo synthesis of methionine methyl groups from one-carbon units furnished by tetrahydrofolate (THF) (figure 1). The enzyme utilises methyl-THF as methyl donor and methylcobalamin as tightly-bound coenzyme. De novo synthesis of methyl groups via this system appears to be minimal when labile methyl group intake is sufficient or excessive (Stipanuk, 1986).

Dietary choline therefore contributes insignificantly to the choline body pool in adult ruminants (Table 1; Figure 3). Methyl group metabolism is generally conservative with a relatively low rate of methyl catabolism and an elevated rate of de novo synthesis of methyl groups via the tetrahydrofolate (THF) system (Girard et al., 2010; Henderson et al., 1983; Robinson et al., 1984; Snoswell \& Xue, 1987; Xue \& Snoswell, 1986a; Xue \& Snoswell, 1986b). In dairy ruminants the situation can be even worse (Table 1): the dietary availability of choline is still low while the output of methylated compounds to milk is particularly high, and methionine, as well as other methyl group sources - one-carbon units for methylneogenesis via the THF system-, is likely to be in short supply, especially at the onset of lactation (Pinotti et al., 2002). In dairy ruminants producing large quantities of milk in fact, methionine is also the first limiting amino acid. This means that the elevated requirement for methionine for transmethylation reactions and milk protein synthesis may lead to altered methyl group metabolism (Girard et al., 2010; LaCount et al., 1995; Lobley et al., 1996). The effects of lactation on methyl group metabolism have been examined in sheep (Xue \& Snoswell, 1985); it was found that the activities of hepatic phospholipid methyltransferase (for phosphatidylcholine synthesis) and methionine synthase were significantly higher (+33\% and $+34 \%$, respectively) in lactating than non-lactating ewes (Xue \& Snoswell, 1985). 


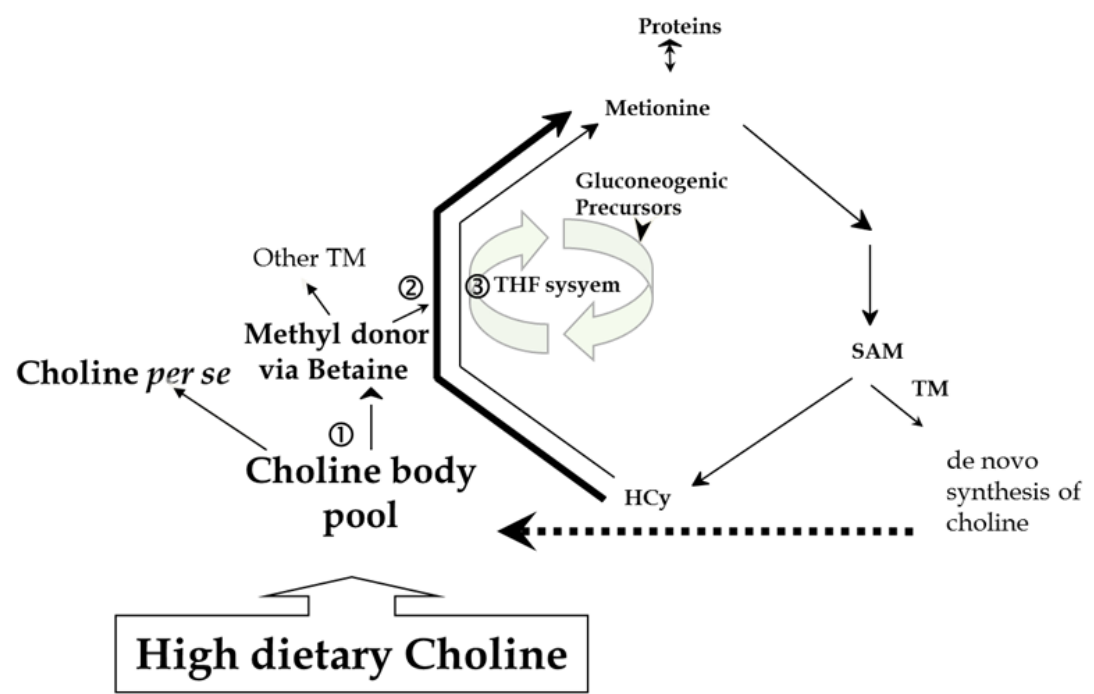

Figure 2. Choline and methyl groups metabolism in pre-ruminants. SAM, S-adenosyl-L-methionine. HCys, Homocysteine. TM, Transamethylation pathway. THF Tetrahydrofolate system. (1) Choline oxidase (EC 1.1.3.17). (2) Betaine-homocysteine methyltransferase (EC 2.1.1.5). (3) Methionine synthase (EC 2.1.1.13). (adapted from Pinotti et al., 2002).

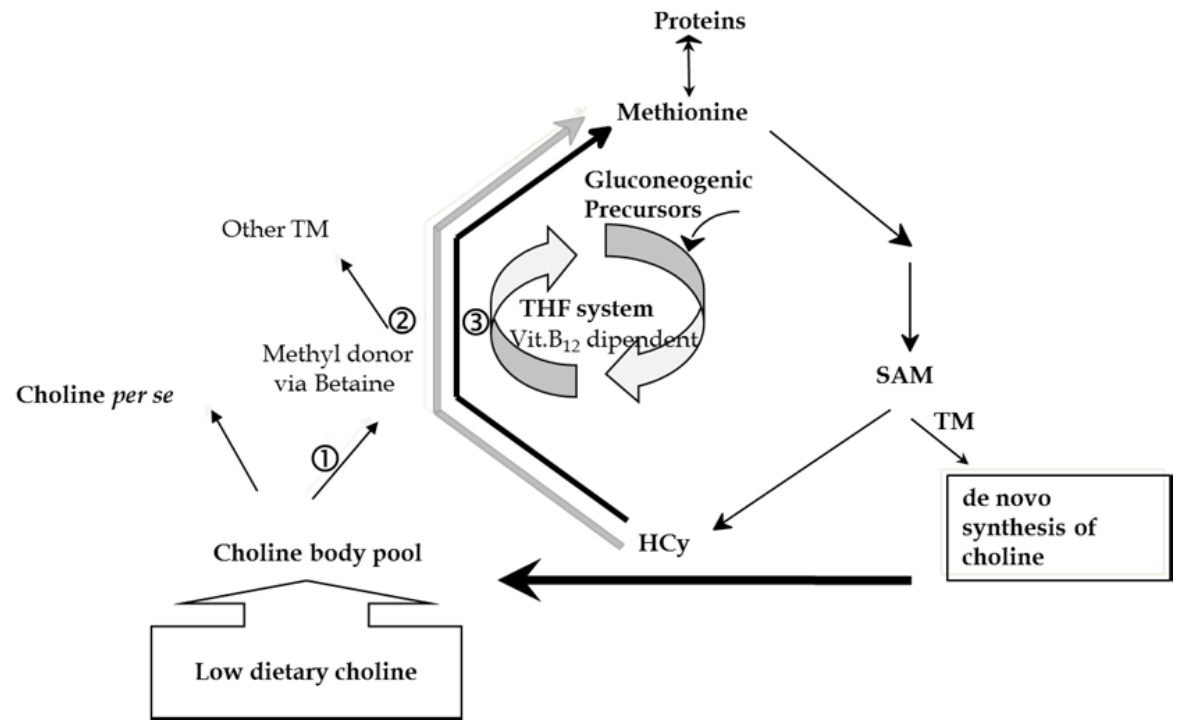

Figure 3. Choline and methyl groups metabolism in adult ruminants in positive energy balance (adapted from Pinotti et al., 2002). SAM, S-adenosyl-L-methionine. HCys, Homocysteine. TM, Transamethylation pathway. THF Tetrahydrofolate system. (1)Choline oxidase (EC 1.1.3.17). (2) Betainehomocysteine methyltransferase (EC 2.1.1.5). (3) Methionine synthase (EC 2.1.1.13). (adapted from Pinotti et al., 2002). 


\begin{tabular}{|c|c|c|}
\hline Physiological Stage & Availability & Enzymes Activities \\
\hline Pre-Ruminants & $\begin{array}{l}\text { i choline } \\
\text { iे betaine }\end{array}$ & $\begin{array}{l}\text { 仓े Cho-oxidase } \\
\text { 仓 Betaine-HCy-methyltransferase }\end{array}$ \\
\hline Adult Ruminants & $\begin{array}{l}\text { 凤 choline } \\
\S \text { betaine } \\
\text { i methyl syntheses via THF }\end{array}$ & i Methionine synthetase \\
\hline Lactating Ruminants & 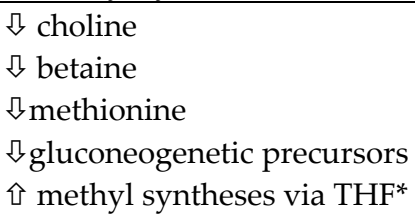 & 仓े Methionine synthetase \\
\hline
\end{tabular}

Table 1. Evolution of metabolism in methyl groups in ruminants in three physiological stages[*at the onset of lactation, the substrates of this path often become limiting](adapted from Pinotti et al., 2002).

\section{Choline in dairy cows nutrition}

The earliest investigations were interested in determining the effects of added dietary choline on milk production. For this purpose supplementation experiments using unprotected choline (Erman et al., 1984; Atkins et al., 1988; Sharma \& Erdman, 1988b), were performed. In these studies using unprotected choline, neither milk production nor milk composition were affected, due, it was suggested, to rapid choline degradation in the rumen (Atkins et al., 1988; Sharma \& Erdman, 1988b). In fact the work of Atkins et al. (1988) indicated that choline chloride was more degradable than naturally occurring choline in feed, while increasing choline chloride intake from 23 to $326 \mathrm{~g} / \mathrm{d}$ only raised duodenal choline flow from 1.2 to $2.5 \mathrm{~g} / \mathrm{d}$, so that recovery was low indeed (Sharma \& Erdman, $1988 \mathrm{~b}$ ). The mean estimates of rumen degradable choline (measured in vitro) actually were $80-98 \%$ for common feedstuffs and supplements (Table 2), indicating that use of choline-rich feedstuffs or additives in diets can only marginally increase the post ruminal flow of choline in ruminants (Sharma and Erdman, 1989a).

However, others studies (Sharma \& Erdman, 1988a; Sharma \& Erdman, 1989b) on the effects of abomasally infused choline, suggested a possible requirement for supplementing choline in lactating dairy cows. For example, Sharma \& Erdman (1988a) investigated abomasal infusion of choline or methionine in dairy cows, either alone or with the choline synthesis inhibitor 2amino-2-methyl-1-propanol (2AMP). They found that abomasal infusion of $30 \mathrm{~g} / \mathrm{d}$ of choline was more effective than abomasal infusion of $45.6 \mathrm{~g} / \mathrm{d}$ methionine (the molar equivalent of $30 \mathrm{~g}$ choline) in increasing milk yield and milk fat content. Additionally, milk production, milk fat percentage, milk fat yield, milk protein percentage, and milk protein yield of cows infused with 2AMP plus methionine were all lower than in cows infused with 2AMP plus choline (Sharma \& Erdman, 1988a). These data suggest not only that supplemental choline is required to achieve maximal performance, but also that choline formed from methionine (Emmanuel \& Kennelly, 1984) may be partially responsible for these stimulatory effects on milk production. Form a technical/feeding point of view these studies also evidenced that choline must be rumen-protected to be effective in dairy cow nutrition. 


\begin{tabular}{|l|c|}
\hline \multicolumn{1}{|c|}{ Feedstuffs } & Effective degradation, $\%$ \\
\hline Barley & 79.4 \\
\hline Cottonseed & 84.7 \\
\hline Soybean meal & 82.9 \\
\hline Fish-meal Supplements & 83.8 \\
\hline \multicolumn{1}{|c|}{ Choline stearate } & 98.0 \\
\hline Choline chloride & 98.6 \\
\hline
\end{tabular}

Table 2. Rumen stability: In vitro choline degradation (Sharma \& Erdman, 1989a). Data obtained during four individual fermentation runs, samples were incubated in vitro with an inoculum mixture containing rumen fluid obtained from a rumen-fistulated dairy cow fed $17.5 \%$ corn silage and $28.7 \%$ grass silage and $53.8 \%$ concentrate diet.

\subsection{Recent advance in choline supplementation in dairy cow}

Although the choline requirement of dairy cows is still unknown (National Research Council, 2001), higher choline availability (by feeding rumen-protected choline, RPC) can have a favorable effect on milk production (Erdman and Sharma 1991; Erdman, 1994; Hartwell et al. 2000; Piepenbrink and Overton 2003; Pinotti et al. 2003; Scheer et al. 2002). In dairy ruminants, in fact choline has been proposed as limiting nutrient, especially at the onset of lactation (Erdman and Sharma 1991; Pinotti et al., 2002). Based on those considerations, the effects of rumen-protected choline (RPC) supplementation to transition cows have been investigated in several studies (figure 4).

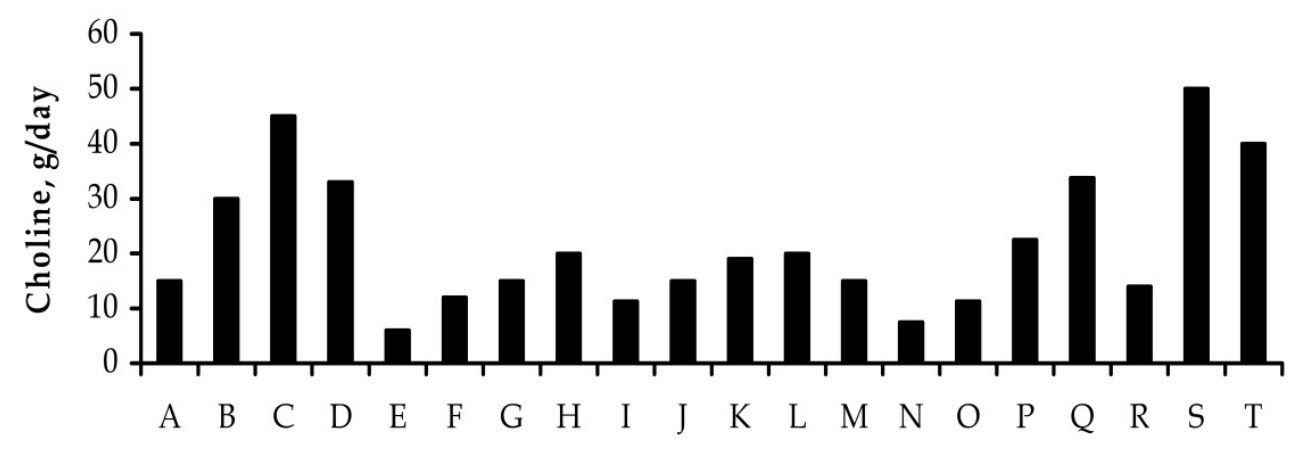

Figure 4. Levels of choline chloride supplementation [provided in a rumen-protected (RP) form] to transition dairy cows in published studies. Citations keys are reported on the $\mathrm{x}$ axis: (A)-(C) Erdman \& Sharma, 1991; (D) Erdman, 1994; (E)- (F) Hartwell et al., 2000; (G) Scheer et al., 2002; (H) Pinotti et al., 2003; (I)-(K) Piepenbrink \& Overton, 2003; (L) Pinotti et al., 2004; (M) Janovick Guretzky at al., 2006; (N)-(Q) Xu et al., 2006; (R) Zahra et al., 2006; (S) Elek et al., 2008; (T) Davidson et al., 2008. Choline chloride supplementation is shown on the y axis. 
Findings in transition and early lactating dairy cows suggest that greater choline availability can improve not only milk production (Erdman and Sharma, 1991; Hartwell et al., 2000; Pinotti et al., 2003), but also lipid (Piepenbrink Overton, 2003; Pinotti et al., 2003), methyl group metabolism (Baldi \& Pinotti, 2006) and choline secretion in milk (Deuchler et al., 1998; Elek et al., 2008; Pinotti et al., 2003; Pinotti et al, 2004). Furthermore, in the Pinotti et al. (2003) study, although plasma concentrations of vitamin E declined after parturition in choline-supplemented animals, the reduction was less than in controls, suggesting improved vitamin E status. However, the mechanisms of this effect have not been elucidated with certainty, even though an improved fat absorption and transport induced by choline supplementation has been proposed (Pinotti et al., 2003). Janovick Guretzky et al. (2006) found that choline supplementation did not affect milk production in either Holstein or Jersey transition cows, but in discussing their results they noted that calculated methionine balance was negative postpartum, so that supplemental choline might not have spared enough methionine to produce a physiological benefit. This conclusion is in line with another study (Brüsemeister \& Südekum, 2006) that, in reviewing several published works on choline supplementation in dairy cows, concluded that negative methionine balance and therefore a basal diet of adequate quality and composition (Baldi \& Pinotti, 2006) - is essential for obtaining a response to rumen-protected choline. A further study of Zahra et al. (2006), reported that choline supplementation improves milk production $(1.2 \mathrm{~kg} /$ day $)$ in the first $60 \mathrm{~d}$ of lactation, although supplementation was only from $21 \mathrm{~d}$ prepartum to 28 days in milk. However, choline's effect on milk yield was attributable mainly to increased milk production ( $4.4 \mathrm{~kg} /$ day) in animals with body condition score $\geq 4$ three weeks before calving, that were also consuming more feed. Supplementation of rumen-protected choline would therefore seem to be essential for optimising high-quality milk production in high-yielding dairy cows, as also reported in subsequent studies (Davidson et al., 2008; Elek et al., 2008; $\mathrm{Xu}$ et al., 2006), particularly in animals fed basal diets that limit post-ruminal methionine supply. The magnitude of the production response is likely to be affected by basal diet composition, the dose and mode of administration of the rumen-protected choline, and the stage of lactation, as discussed elsewhere (Baldi \& Pinotti, 2006; National Research Council, 2001).

With regard to metabolic health, few studies in dairy cow also investigated the effects of choline supplementation on lipid metabolism (Piepenbrink \& Overton, 2003; Pinotti et al. 2003; Pinotti et al. 2004 ), and hepatic lipidosis (Grummer, 2006; van Vuuren et al., 2010). In dairy ruminants it is known that the necessity to increase the lipolysis of adipose fat stores is most critical during the first stage of lactation (Grummer, 1993; McCarthy et al., 1968). During this stage, fat mobilisation leads to increased blood levels of non-esterified fatty acids (NEFA) which are taken up by the liver and oxidised to ketone bodies or carbon dioxide or esterified to triglycerides. The liver normally packages the triglycerides in VLDLs and secretes them, but sudden increases in plasma NEFA may not be adequately processed by the ruminant liver (Gruffat et al., 1996; Pullen et al., 1990). Choline serves as methyl donor in the synthesis of carnitine (Griffith, 1987) which is essential for fatty acid oxidation. 
The esterification of NEFA to triglycerides, and their secretion to VLDL also involves choline (Gruffat et al., 1996). In this context the NEFA/cholesterol ratio can be considered a measure of the fat retained in or metabolized by the liver and its lowered value observed in RPC cows suggested a lower risk of fatty liver in these animals (Holtenius, 1989). Thus the lowered plasma NEFA levels and the NEFA/cholesterol ratio in RPC-supplemented cows at parturition suggest more efficient liver function and improved lipid metabolism in general (Pinotti et al. 2003).

A subsequent study (Pinotti et al. 2004) provided similar results, in that plasma NEFA was reduced by $18 \%$ on day 20 of lactation in supplemented animals. Likewise, Chung et al. (2009) found that RPC have a dose dependent effect on reducing plasma NEFA concentration by $11 \%$ and $23 \%$ in cows receiving $25 \mathrm{~g}$ and $50 \mathrm{~g}$ of rumen-protected choline. These findings are also consistent with the evidence that RPC supplementation to dairy cows throughout the periparturient period decreased liver accumulation of lipids (stored as intracellular triglycerides- van Vuuren et al., 2010) and increased liver glycogen content (Piepenbrink \& Overton, 2003). The effects of choline at liver level have been recently confirmed in transition dairy cows (van Vuuren et al., 2010), in which RPC supplementation resulted in lower TAG concentration, by $36 \%$ and $32 \%$ compare to untreated animals, in week 1 and 3 post-partum, respectively. Results obtained in these studies indicated that not only hepatic fatty acid metabolism and cow performance are responsive to increasing the supply of choline (Piepenbrink \& Overton, 2003), but also that choline supplementation can reduce cellular lipid accumulation in the liver especially during the transition period.

A further aspect investigated in some of these studies was the effect of choline on methyl group status of lactating cows. Studies carried out by Pinotti et al. (2004) showed that the administration of $50 \mathrm{~g}$ of (RPC, providing $20 \mathrm{~g}$ of choline chloride) to transition dairy cows increased plasma levels of choline-containing phospholipids and folates by the end of the transition period ( 20 days in milk). These findings indicate that that RPC supplementation is effective both in increasing choline availability and in optimizing methyl group metabolism: the increase in plasma folates may be attributable to a sparing effect of choline on methyl group metabolism. As noted, choline is an important source of labile methyl groups, but when it is in short supply, methyl groups (e.g. for methionine resynthesis from homocysteine) must be synthesized de novo by the THF system or derived from other sources. The THF system consumes gluconeogenic precursors, so in periods of glucose imbalance (e.g. early lactation) such precursors can also be limiting (Armentano 1994; Rukkwamsuk et al. 1999). An unexpected finding of studies in this area is that plasma vitamin B12 concentrations in RPC-supplemented cows were lower than in controls (Baldi \& Pinotti 2006). Vitamin B12 is considered a marker of methyl group status, and the lower concentrations in treated animals appear inconsistent with the observed increases in plasma folates and choline-containing phospholipids. However, vitamin B12 is required as a coenzyme in the biosynthesis of methionine from homocysteine and in gluconeogenesis from propionate. Increased gluconeogenesis may therefore deplete vitamin B12, as indicated 
by the finding of a tendency toward higher concentrations of plasma glucose in RPCsupplemented cows. Nevertheless, these results were obtained from a limited number of animals, and therefore they should considered with caution since our knowledge of the interaction of choline with vitamins and other essential nutrients are incomplete.

\subsection{Systematic analysis of choline supplementation in dairy cows}

In the recent past different models (linear and logistic) were developed to permit the calculation of changes in milk yield and milk composition from amounts of rumenprotected choline in dairy cow diets. For example, Pinotti et al. (2010) investigated the effects of RPC administration on milk production by a regression model based on the results of 11 different studies (42 experimental groups) published between 1991 and 2008 (Davidson et al., 2008; Deuchler et al., 1998; Elek et al., 2008; Erdman et al., 1991; Hartwell et al., 2000; Janovick Guretzky et al., 2006; Pipenbrink and Overton, 2003; Pinotti et al., 2003; Pinotti et al., 2004; Xu et al., 2006; Zahra et al., 2006). The analysis included RPC supplementation (control/RPC) as fixed effect, the variability among experiments as random effect and their interaction. Treatments schedule, dry matter intake and dietary composition, accounted for most of the variability among experiments and were highly correlated in a preliminary data analysis; therefore, these variables were considered as experimental effects and treated as random components in the mixed model, assuming that the results of different experiments are affected by different experimental conditions. For each study, data were also weighted by the reciprocal of the squared standard error of the mean value, in order to consider the unequal variance among studies.

\begin{tabular}{|l|c|c|}
\hline \multicolumn{1}{|c|}{ Choline amount administered } & Milk yield estimate $(\mathrm{kg} / \mathrm{d})$ & RPC effect \\
\hline Control $(0 \mathrm{~g} / \mathrm{d})$ & 32.35 & - \\
\hline RPC low level $(<10 \mathrm{~g} / \mathrm{d})$ & 33.40 & 0.15 \\
\hline RPC high level $(>10 \mathrm{~g} / \mathrm{d})$ & 35.18 & $<0.001$ \\
\hline
\end{tabular}

Table 3. Results from mixed model when the different amounts of RPC administrated were grouped into three supplementation levels (adapted from Pinotti et al., 2010).

The data reviewed in this analysis were consistent with the fact that choline supplementation significantly increased milk yield in dairy cows, even though, as expected, the dose of choline administered is also relevant (table 3). Considering three supplementation classes, i.e. control (no choline: $0 \mathrm{~g} / \mathrm{d}$ ), low level $(<10 \mathrm{~g} / \mathrm{d}$ of choline chloride in a rumen protected form) and high level $(>10 \mathrm{~g} / \mathrm{d}$ of choline chloride in a rumen protected form), the meta-analysis indicated that a low level (less than $10 \mathrm{~g}$ per day) of RPC supplementation tended to increase milk yield and a high level of supplementation of RPC significantly increased milk yield. This results were in line with another meta-analysis, 
performed using a nonlinear model (Sales et al., 2010), on the effects of rumen-protected choline in dairy cows, in which choline supplementation has a positive effect on milk yield and milk protein content, but not on milk fat content.

\section{Other dairy ruminant}

In the case of small ruminants the effects of choline infusion on transmethylation reactions have been studied in sheep by Lobley et al. (1996), while Emmanuel and Kennely (1984) investigated methionine and choline incorporation into plasma and milk of lactating goats. More recently Banskalieva et al. (2005) assessed the efficacy of rumen-protected choline supplementation in meat goats. However, studies on choline supplementation and its effects on milk production, and lipid and methyl group status in periparturient dairy goats have been published only recently (Pinotti et al., 2008; Savoini et al., 2010). In a production trial (Pinotti et al., 2008) a supplementation of $4 \mathrm{~g} / \mathrm{d}$ of choline in rumen protected form was given to periparturient dairy goats, starting 4 weeks prior to expected kidding and continuing for 5 weeks after parturition. The quantity of choline given was based on experiments in dairy cows (Pinotti et al., 2005) and metabolic Body weight $\left(\mathrm{BW}^{0.75}\right)$ of the goats at the beginning of the experiment. During the first 6 weeks of lactation, milk yield and four percent fatcorrected milk (FCM) yield were increased by 7 and $12 \%$, respectively, in RPC supplemented than non-supplemented goats. Milk fat concentration, fat and protein yield were also increased by RPC treatment. The link between choline supplementation and milk response has been mainly attributed to the metabolic interchangeability of choline and methionine, in the sense that both can furnish labile methyl groups. This interchangeability has been investigated by Emmanuel and Kennelly (1984) in goats, who estimated that $6 \%$ of the choline pool was derived from methionine and that approximately $28 \%$ of methionine is used for choline synthesis via the pathway for the de novo biosynthesis of the choline moiety involving sequential methylation of phosphatidylethanolamine. Reduction of methyl group demands from the methionine pool may therefore offer production benefits to dairy ruminants and might be achieved by nutritional manipulation other than alteration of the methionine supply (Lobley et al., 1996). This was probably the situation in the study by Pinotti and coworkers (2008), in which during the early stages of lactation of dairy goats dietary methionine was probably limiting (goats received about $80 \%$ of the optimal level of methionine). These considerations imply that feed composition, mainly protein supply and the availability of methionine (National Research Council, 2001) influence the effects of choline supplementation not only in dairy cows (Baldi \& Pinotti, 2006; Brüsemeister \& Südekum, 2006), but also in goats.

The milk production response to choline supplementation in dairy goats, was obtained without any detrimental effect on methyl groups status. In fact, folate availability at kidding was higher in choline-supplemented than in non-supplemented goats, while during lactation lack of a drop in plasma folate and vitamin B12 in the choline-supplemented animals, suggests that good methyl group status was maintained in choline-treated goats 
(Pinotti et al., 2008; Savoini et al., 2010). This results was obtained, even though RPC receiving goats were producing more milk than the choline un-suplemented ones.

In a parallel study (Baldi et al. 2011) the effect of rumen-protected choline administration on metabolic profile, selected liver constituents, and on mRNA expressions of selected enzymes, transcription factors, and nuclear receptors involved in mammary lipid metabolism in dairy goats, have been investigated. It was evident from this study that at comparable milk yield during the first month of lactation, choline supplemented goats showed a lower level of plasma $\beta$-hydroxybutyrate, whereas no other differences were observed for other metabolites. The reasons for this difference are uncertain: authors conjecture that it might be due to the role of choline in lipid metabolism as already reported in dairy cows (Baldi \& Pinotti, 2006; Chung et al., 2009). With regard to liver variables, it has been reported that total liver lipid/ DNA content was significantly lower (-35\%) in RPC than CTR goats. As already reported above, dairy cows receiving choline have also been reported to have reduced hepatocellular lipid accumulation (Cooke et al., 2007; Grummer, 2006).

Within the mammary tissue many selected enzymes [e.g. lipoprotein lipase (LPL)], transcription factors and nuclear receptors that can be affected by choline availability are involved in lipid uptake and milk fat secretion. Furthermore, choline is actively secreted into mammalian milk. The major choline-containing compounds in bovine milk are unesterified choline, phosphatidylcholine, and sphingomyelin (Pinotti et al., 2003). Kinsella (1973) reported that a bovine mammary gland yielding 25 litres milk secretes $10 \pm 3 \mathrm{~g}$ phospholipids per day, corresponding on average to $5 \%$ of the phospholipids of the mammary tissue. The phospholipids of the membrane of the milk fat globule constitute the major cholinecontaining component of bovine milk (McPherson \& Kitchen, 1983). The above data suggest that choline is an important metabolite in lactating mammary tissue, that it is used avidly when available (Kinsella, 1973), mainly in the lipid metabolism. Thus, it has been proposed that choline supplementation can have positive effects on lipid trafficking particularly lipid transport to and within extra-hepatic tissues (Baldi \& Pinotti, 2006; Cooke et al., 2007; Piepenbrink \& Overton, 2003) including the mammary gland. However, at udder level in lactating goats, choline did not affect the expression of several mammary gland transcripts involved in lipid metabolism (Baldi et al. 2011). The effects of nutrition on the expression of mammary lipogenic genes in dairy ruminants (cows, ewes, goats) have been investigated mainly by feeding milk-fat depressing diets, characterized by high levels of concentrates, or conjugated linoleic acids (CLA), or other lipids (fish oil, vegetable oils, full fat seeds, etc.) (Bauman, 2008; Bernard et al., 2006; Harvatine and Bauman 2006; Lock et al., 2008). Absence of significant effects on gene expression observed in goats could be due to the dose or to the type of supplementation. Thus, while in Baldi et al. (2011) were supplied $4 \mathrm{~g} / \mathrm{d}$ choline (about $0.2 \%$ of DMI), other studies used higher levels of supplementation (for fats 3.6-11.2\% of DMI) or more potent nutritional factors (e.g. CLAs are potent inhibitors of mammary gland fat synthesis) (see Bernard et al., 2006 for review). Nevertheless, these results were obtained from a limited number of animals, and choline effects and function in lactating mammary tissue deserve further investigation. 


\section{Conclusions}

It can be concluded from this outline that dietary supply of choline may not always be sufficient to maximize milk production in both dairy cows and goat; and although the requirement for choline can in theory be satisfied by other nutrients, it is unlikely that this happens in practice especially at the onset of lactation. The magnitude of the production response is likely to be affected by basal diet composition, the dose of the rumen-protected choline, and the stage of lactation (Baldi \& Pinotti, 2006; National Research Council 2001). In particular with respect to lactation cycle several studies provided convincing evidence that protected choline positively affects lactation performance especially when feeding is initiated prior to calving and is continued during early lactation (Grummer, 2011). In fact, assuming that choline is limiting in high yielding dairy ruminants, the greatest demand for choline should occur at lactation onset. It is also at this stage that the availability of other choline-related nutrients (i.e. methionine, folates, and vitamin B12) is often low (Baldi \& Pinotti, 2006; Girard et al., 2010). From a metabolic and hephatic point of view, since choline is a lipotropic factor, it may be particularly beneficial at this time in view of the adipose and liver metabolism changes that occur during the transition from late pregnancy to early lactation (Piepenbrink and Overton 2003): choline may optimize the balance between fat retained and fat metabolized by the liver, thereby improving lipid metabolism in general. These roles of choline however, do not exclude that RPC supplementation is also effective in optimizing methyl group metabolism, which might be an added benefit of adequate choline supplementation. With regard to dose, even though an estimate of the minimum choline needed in dairy cows for maintenance functions (based on metabolic body size), is approximately 4 to $6 \mathrm{~g}$ /day (Donkin, 2011), production response were abstained when higher doses were fed (Pinotti et al., 2010). Consequently, although insufficient data are available to establish the choline requirement, it can be suggested that supplementation doses in this range are likely to be adequate for transition dairy ruminants.

However, it is also evident that our knowledge of the interaction of choline with vitamins and other essential nutrients is incomplete in the dairy ruminants. For example there are indications that both methyl group precursors (including choline) and appropriate co factors (folate and vitamin B12) are important for the optimal metabolic support of milk production (Pinotti et al., 2008), even though methionine may not always be involved in this scenario (Preynat et al, 2009).These aspects not only reflect the inadequacy of a nutritional approach based on the supply and utilisation of individual nutrients, but also suggest that the requirements of B-complex vitamins in dairy ruminants should be reconsidered.

\section{Author details}

Luciano Pinotti

Department of Health, Animal Science and Food Safety, Università di Milano, Italy 


\section{Acknowledgment}

This chapter has been developed in the frame of the COST Action FA0802 Feed for Health. The author wish also to thanks Dr. Gerwin Meijer from the Animal Science Group, Wageningen University, for his advisor in the early literature study on this topic, Prof. Antonella Baldi and Prof. Vittorio Dell'Orto, as well as all the member of the Animal Nutrition Research Group from the Veterinary Medicine Faculty of the Università di Milano (Italy), for their collaboration and support in several experiments carried out in this area.

\section{References}

Armentano L. (1994). Impact of metabolism by extragastrointestinal tissues on secretory rate of milk proteins. Journal of Dairy Science, Vol. 77, No. 9, (September 1994), pp. 28092820., ISSN: 0022-0302

Atkins, K. B.; Erdman, R. A. \& Vandersall, J. H. (1988). Dietary choline effects on milk yield and duodenal choline flow in dairy cattle. Journal of Dairy Science, Vol. 71, No. 1, January 1988, pp. 109-116, ISSN: 0022-0302

Baldi, A.; Bruckmaier, R., D’ambrosio, F., Campagnoli, A., Pecorini, C., Rebucci R., \& Pinotti, L. (2011). Rumen-protected choline supplementation in periparturient dairy goats: effects on liver and mammary gland. Journal of Agricultural Science, Vol. 150, No. FirstView, Jenuary 2011, pp 1-7,DOI ISSN: 0021-8596 DOI:10.1017/S0021859611000104

Baldi, A. \& Pinotti, L. (2006). Choline metabolism in high-producing dairy cows; metabolic and nutritional basis. Canadian Journal of Animal Scicience, Vol 86, No. 2, June 2006, pp. 207-212. ISSN 1918-1825

Banskalieva, V.; Puchala, R., Goetsch, A.L., Luo, J., \& Sahlu T. (2005). Effects of ruminally protected betaine and choline on net flux of nutrients across the portal-drained viscera and liver of meat goat wethers consuming diets differing in protein concentration. Small Ruminant Research, Vol. 57, No. 2-3, (March 2005), pp. 193-202, ISSN 0921-4488.

Bauman, D.E.; Perfield, J.W., Harvatine, K.J. \& Baumgard, L.H. (2008). Regulation of Fat Synthesis by Conjugated Linoleic Acid, Lactation and the Ruminant Model. Journal of Nutrition, Vol. 138, No. 2 (February, 2008), pp. 403-409, ISSN 1541-6100

Bernard, L.; Leroux, C. \& Chilliard, Y. (2006). Characterisation and nutritional regulation of the main lipogenic genes in the ruminant lactating mammary gland. In, Ruminant physiology, digestion, metabolism and impact of nutrition on gene expression, immunology and stress, Sejrsen, K., Hvelplund, T. \& Nielsen, M.O. (Ed.), 295-326, Wageningen Academic Publishers, ISBN 978-953-7619-81-7 Wageningen, The Netherlands.

Brüsemeister, F. \& Sudekum, K.H. (2006). Rumen-protected choline for dairy cows: the in situ evaluation of a commercial source and literature evaluation of effects on performance and interactions between methionine and choline metabolism. Animal Research, Vol. 55, No. 2 (March-April 2006), pp. 93-104, ISSN 1627-3591 
Chung, Y.-H.; Brown, N. E., Martinez, C. M., Cassidy, T. W. \& Varga, G. A. (2009). Effects of rumen-protected choline and dry propylene glycol on feed intake and blood parameters for Holstein dairy cows in early lactation. Journal of Dairy Science, Vol. 92, No. 6, (June 2009), pp. 2729-2736, ISSN 0022-0302

Cooke, R.F.; Silva Del Río, N., Caraviello, D.Z., Bertics, S.J., Ramos, M.H. \& Grummer, R.R. (2007). Supplemental Choline for Prevention and Alleviation of Fatty Liver in Dairy Cattle. Journal of Dairy Science, Vol. 90, No. 5, May 2007, pp. 2413-2418, ISSN $0022-$ 0302

Davidson, S.; Hopkins, B.A., Odle, J., Brownie, C., Fellner, V. \& Whitlow, L.W. (2008). Supplementing limited methionine diets with rumen-protected methionine, betaine, and choline in early lactation holstein cows. Journal of Dairy Science, Vol. 91, Vol. 91, No. 4 (April 2008), pp 1552-1559, ISSN 0022-0302

Dawson, R. M. C.; Grime, D. W., \& Lindsay, D. B. (1981). On the insensitivity of sheep to the almost complete microbial destruction of dietary choline before alimentary-tract absorption. Biochemical Journal, Vol. 196, No. 2 (May 1981), pp. 499-504, ISSN 14708728

Deuchler, K. N.; Piperova, L. S. \& Erdman, R. A. (1998). Milk choline secretion as an indirect indicator of postruminal choline supply. Journal of Dairy Science, Vol. 81, No. 1, (January 1998), pp. 238-242, ISSN 0022-0302

Dilger, R.N.; Garrow, T. A., \& Baker, D. H. (2007). Betaine can partially spare choline in chicks but only when added to diets containing a minimal level of choline. Journal of Nutrition, Vol. 137, No. 10 (October 2007), pp. 2224-2228, ISSN 0022-3166

Donkin, S.S., (July, 2011) Rumen-Protected Choline, 11.07.2011, Available from http://www.extension.org/pages/26158/rumen-protected-choline\#

Elek, P.; Newbold, J.R., Gaal, T., Wagner, L. \& Husveth, F. (2008). Effects of rumen-protected choline supplementation on milk production and choline supply of periparturient dairy cows. Animal, Vol. 2, No. 11 (November 2008), pp.1595-1601.

Emmanuel, B. \& Kennelly, J. J. (1984). Kinetics of methionine and choline and their incorporation into plasma lipids and milk components in lactating goats. Journal of Dairy Science, Vol. 67, No. 9 (September 1984), pp. 1912-1918, ISSN 00220302

Erdman, R. A. \& Sharma, B. K. (1991). Effect of dietary rumen-protected choline in lactating dairy cows. Journal of Dairy Science, Vol. 74, No. 5 (May 1991), pp. 1641-1647, ISSN 00220302

Erdman, R. A. (1994). Production responses in field study herds fed rumen protected choline. Journal of Dairy Science, Vol. 77(Suppl. 1), pp 186. (Abstr.) , ISSN 00220302

Erdman. R. A.; Shaver, R. D., \& Vandersall, J. H. (1984). Dietary choline for the lactating cow: possible effects on milk fat synthesis. Journal of Dairy Science, Vol. 67, No. 2 (February 1984), pp. 410-415, ISSN 0022-0302 
Food and Nutrition Board (1998), Institute of Medicine. Choline, In Dietary Reference Intakes: Thiamin, Riboflavin, Niacin, Vitamin B-6, Vitamin B012, Pantothenic Acid, Biotin, and Choline, National Academy of Sciences, ISBN 0-39-06554-2, pp 390-422, Washington, D.C., US

Girard, C. L.; Preynat, A., Graulet, B \& Lapierre, H. (2010). Could 'minor' nutrients such as B vitamins alter major metabolic pathways in lactating dairy cows?, In: Energy and protein metabolism and nutrition, G.M. Crovetto (Ed.), pp. 235-243, Wageningen Academic Publishers (EAAP publication N¹27), ISBN978-90-8686-153-8, Wageningen. The Netherlands

Griffith O. W. (1987). Mammalian sulfur amino acid metabolism: an overview. Methods Enzymology, Vol. 143, pp 366-376, ISSN 0076-6879

Gruffat, D.; Durand, D., Graulet, B., \& Bauchart, D. (1996). Regulation of VLDL synthesis and secretion in the liver. Reproduction Nutrition Development, Vol. 36, No. 4, pp. 375-389. ISSN 1297-9708

Grummer, R. R. (1993). Etiology of lipid related metabolic disorders in periparturient dairy cattle. Journal of Dairy Science, Volume 76, No. 12 (December 1993), pp. 3882-3896, ISSN 0022-0302

Grummer, R.R. (2006). Etiology, pathophysiology of fatty liver in dairy cows. In Production diseases in farm animals, Joshi, N.P. \& Herdt, T.H. (Ed.), pp. 141-153. Wageningen Academic Publishers, ISBN 9076998574, Wageningen. The Netherlands

Grummer, R.R. (July 2011). Managing the Transition Cow-Emphasis on Ketosis and Fatty Liver Syndrome, 15.07.2011, Available from

http://www.vtdairy.dasc.vt.edu/pdf/cow_college/2011/18\%20grummer-paper.pdf

Hartwell, J. R.; Cecava, M. J. \& Donkin, S. S. (2000). Impact of dietary rumen undegradable protein and rumen-protected choline on intake, peripartum liver triacylglyceride, plasma metabolites and milk production in transition dairy cows. Journal of Dairy Science, Vol. 83No. 12 (December 2000), pp. 2907-2917, ISSN 0022-0302

Harvatine, K.J. \& Bauman, D.E. (2006). SREBP1 and thyroid hormone responsive spot 14 (S14) are involved in the regulation of bovine mammary lipid synthesis during dietinduced milk fat depression and treatment with CLA. Journal of Nutrition 136, No. 10 (October 2006), pp. 2468-2474.

Henderson, G. D.; Xue, G. P. \& Snoswell, A. M. (1983). Carnitine and creatine content of tissues of normal and alloxan-diabetic sheep and rats. Comparative Biochemistry and Physiology Part B: Comparative Biochemistry, Vol. 76B, No. 2, pp. 295-298, ISSN: 10964959

Holtenius, P. (1989). Plasma lipids in normal cows around partus and in cows with metabolic disorders with and without fatty liver. Acta Veterinaria Scandinavica, Vol. 30, No. 4 (December 1989), pp. 441-445, ISSN: 1751-0147

Janovick Guretzky, N.A.; Carlson, D.B., Garrett, J.E. \& Drackley, J.K. (2006). Lipid metabolite profiles and milk production for holstein and jersey cows fed rumen-protected choline 
during the periparturient period. Journal of Dairy Science, Vol. 89, No. 1, (January 2006), pp. 188-200, ISSN 0022-0302

Kempson, S.A. \& Montrose, M.H. (2004). Osmotic regulation of renal betaine transport: transcription and beyond. Euroopean Journal Physiology, Vol. 449, No. 3 (December 2004), pp. 227-234 ISSN0 031-6768

Kennedy, G. D.; Young, P. B., Kennedy, S., Scott, J. M., Molloy, A. M., Weir, D. G., \& Price J. (1995). Cobalt-vitamin B-12 deficiency and the activity of methylmalonyl CoA mutase and methionine synthase in cattle. International Journal for Vitamin and Nutrition Research, Vol. 65, No. 4, pp. 241-247, ISSN: 03009831

Kinsella, J. E. (1973). Preferential labelling of phosphatidylcholine during phospholipid synthesis by bovine mammary tissue. Lipids, Vol. 8, No. 7 (July 1973), pp. 393-400, ISSN 0024-4201

Kuksis, A. \& Mookerjea, S. (1978). Choline. Nutrition Reviews, Vol. 36, No. 7 (July 1978), pp. 201-207, ISSN: 0029-6643

LaCount, D. W.; Drackley, J. K., \& Weigel, D. J. (1995). Responses of dairy cows during early lactation to ruminal or abomasal administration of L-carnitine. Journal of Dairy Science, Vol. 78, No. 8 (August 1995), pp. 1824-1836, ISSN 0022-0302

LaCount D. W.; Emmert L. S., \& Drackley J. K. (1996). Dose response of dairy cows to abomasal administration of four amounts of L-carnitine. Journal of Dairy Science, Vol. 79, No. 4 (April 1996), pp. 591-602, ISSN 0022-0302

Lobley, G. E.; Connell, A., \& Revell, D. (1996). The importance of transmethylation reactions to methionine metabolism in sheep: effect of supplementation with creatine and choline. British Journal of Nutrition, Vol. 75, No. 1 (January 1996), pp. 47-56, ISSN 14752662

Lock, A.L.; Rovai, M., Gipson, T.A., De Veth, M. J. \& Bauman, D. E. (2008). A conjugated linoleic acid supplement containing Trans-10, Cis-12 Conjugated Linoleic Acid reduces milk fat synthesis in lactating goats. Journal Dairy Science, 91, No. 9 (September 2008), pp. 3291-3299, ISSN 0022-0302

Mato, J. M.; Alvarez, L., Corrales, F. J., \& Pajares, M. A. (1994). S-adenosylmethionine and the liver. In The Liver: Biology and Pathobiology, I. M. Arias, J. L. Boyer, N. Fausto, W. B. Jakoby, D. A. Schachter, \& D. A. Shafritz (Ed.), pp. 461-470, Raven Press Ltd, ISBN 07817-0133-3, New York, US

McCarthy, R. D.; Porter, G. A., \& Griel, L. C., Jr. (1968). Bovine ketosis and depressed fat test in milk: a problem of methionine metabolism and serum lipoprotein aberration. Journal of Dairy Science, Vol. 51, No. 6 (June 1968), pp. 459-462, ISSN 0022-0302

McCarthy, R. D.; Porter, G. A. \& Griel Jr., L.C. (1968). Bovine ketosis and depressed fat test in milk: a problem of methionine metabolism and serum lipoprotein aberration. Journal of Dairy Science, Vol.51, No.3, (March 1968), pp. 459-462, ISSN 0022-0302

McDowell, L.R. (1989). Choline. In: Vitamins in animal nutrition: comparative aspect to human nutrition, L.R. McDowell (Ed.), New York: Academic Press, Inc., pp. 347-364, ISBN 0-12438372-1 
McPherson, A. V. \& Kitchen, B. J. (1983). Reviews of the progress of dairy science: the bovine milk fat globule membrane-its formation, composition, structure and behaviour in milk and dairy products. Journal of Dairy Research, Vol.50, No.1, pp. 107-133, ISSN: 0022-0299

Moore, J. H. \& Christie, W. W. (1981). Lipid metabolism in the mammary gland of ruminant animals. In: Lipid Metabolism in Ruminant Animals. W.W. Christie (Ed.), Pergamon Press, pp. 227-278, ISBN 0-08-023789-4, Oxford, UK.

Neill, A. R.; Grime, D. W. \& Dawson, R. M. C. (1978). Conversion of choline methyl groups through trimethylamine into methane in the rumen. Biochemical Journal, Vol.170, No. 3, pp. 529-535, ISSN 0264-6021

Neill, A. R.; Grime, D. W.; Snoswell, A. M.; Northrop, A. J.; Lindsay, D. B. \& Dawson, R. M. C. (1979). The low availability of dietary choline for the nutrition of the sheep. Biochemical Journal, Vol.180, No. 3, pp. 559-565, ISSN 0264-6021

National Research Council (2001). Vitamins. In: Nutrient Requirements of Dairy cattle, Seventh Revised Edition, Subcommittee on Dairy Cattle Nutrition, Committee on Animal Nutrition, Board on Agriculture and Natural Resource, pp. 162-177, National Academy Press, ISBN-10:0-309-06997-1 Washington DC:

Preynat A.; Lapierre, H., Thivierge, M.C., Palin, M.F., Matte, J.J., Desrochers, A., \& Girard, C.L. (2009). Effects of supplements of folic acid, vitamin B12, and rumenprotected methionine on whole body metabolism of methionine and glucose in lactating dairy cows. Journal Dairy Science, Vol. 92, No.2 (January 2009), pp 677-689, ISSN 00220302

Piepenbrink, M.S. \& Overton, T.R. (2003). Liver metabolism and production of cows fed increasing amounts of rumen-protected choline during the periparturient period. Journal Dairy Science, Vol.86, No. 5, (May 2003), pp. 1722-1733, ISSN 00220302

Pinotti, L.; Baldi, A.; Politis, I.; Rebucci, R.; Sangalli, L. \& Dell'Orto, V. (2003). Rumen protected choline administration to transition cows: effects on milk production and Vitamin E status. Journal of Veterinary Medicine Series A, Vol.50, (February 2003) No.1, pp. 18-21, ISSN 0931-184X

Pinotti, L.; Baldi, A. \& Dell'Orto, V. (2002). Comparative mammalian choline metabolism with emphasis on role in ruminants, especially the high yielding dairy cow. Nutrition Research Review, Vol. 15, No.2, (December 2002), pp. 315-331L, ISSN 09544224

Pinotti L.; A. Campagnoli, V. Dell'Orto, A. Baldi (2005). Choline: Is there a need in lactating dairy cow? Livestock Production Science, Vol. 98, No. 1-2 (1 December 2005), pp 149-152, ISSN: 0301-6226

Pinotti, L.; Campagnoli, A.; Sangalli, L., Rebucci, R., Dell'Orto, V. \& Baldi, A. (2004). Metabolism of periparturient dairy cows fed rumen-protected choline. Journal Animal and Feed Science, Vol.13, Suppl. 1 (August 2004), pp. 551-554, ISSN 1230-1388 
Pinotti, L.; Polidori, C., Campagnoli, A., Dell'Orto, V. \& Baldi, A. (2010). A meta-analysis of the effects of rumen protected choline supplementation on milk production in dairy cows. In: Energy and protein metabolism and nutrition, G.M. Crovetto (Ed.), pp. 321-322, Wageningen Academic Publishers (EAAP publication N¹27) ISBN978-90-8686-153-8, Wageningen, The Netherlands.

Pullen, D.L.; Liesman, J. S. \& Emery, R. S. (1990). A species comparison of liver slice synthesis and secretion of triacylglycerol from non-esterified fatty acids in media. Journal of Animal Science, Vol.68, No.5, (May 1990), pp. 1395-1399, ISSN 00218812

Robinson, B. S.; Snoswell, A. M., Runciman, W. B. \& Upton, R. N. (1984). Uptake and output of various forms of choline by organs of conscious chronically catherized sheep. Biochemical Journal, Vol. 217, No. 2, pp. 399-408, ISSN 0264-6021

Ruiz, N.; Miles R. D. \& Harms, R. H. (1983). Choline, methionine and sulphate interrelationships in poultry nutrition - A review. World's Poultry Science Journal, Vol.39, pp. 185-198, ISSN 0043-9339

Rukkwamsuk, T.; Wensing, T. \& Geelen, M. J. H. (1999). Effect of fatty liver on hepatic gluconeogenesis in periparturient dairy cows. Journal of Dairy Science, Vol. 82, No.3, (March 1999), pp. 500-505, ISSN 0022-0302

Sales, J.; Homolkaa, P. \& Koukolováa, V. (2010). Effect of dietary rumen-protected choline on milk production of dairy cows: A meta-analysis. Journal of Dairy Science, Vol. 93, No. 8, (August 2010), pp. 3746-3754, ISSN 0022-0302

Savoini, G.; Agazzi, A., Invernizzi, G., Cattaneo, D., Pinotti, L., \& Baldi, A. (2010). Polyunsaturated fatty acids and choline in dairy goats nutrition: production and health benefits. Small Ruminants Research, Vol. 88, No. 1-2 (February 2010), 135-144, ISSN 09214488

Scheer, W.A.; Lucy, M.C., Kerley, M.S. \& Spain, J. N. (2002). Effects of feeding soybeans and rumen protected choline during late gestation and early lactation on performance of dairy cows. Journal of Dairy Science, Vol. 85, Suppl.1, pp. 276, ISSN 0022-0302

Scott, J. M. (1999). Folate and vitamin B12. Proceedings of the Nutrition Society, Vol. 58, No. 2 (June 1999) pp. 441-448, ISSN 0029-6651

Sharma, B. K. \& Erdman, R. A. (1988a). Abomasal infusion of choline and methionine with or without 2-amino-2-methyl-1-propanol for lactating dairy cows. Journal of Dairy Science, Vol. 71, No. 9, (September 1998), pp. 2406-2411, ISSN 0022-0302

Sharma, B. K. \& Erdman, R. A. (1988b). Effects of high amounts of dietary choline supplementation on duodenal choline flow and production responses of dairy cows. Journal of Dairy Science, Vol. 71, No.10, (October 1988), pp. 2670-2676, ISSN 00220302

Sharma, B. K. \& Erdman, R. A. (1989a). In vitro degradation of choline from selected feedstuffs and choline supplements. Journal of Dairy Science, Vol. 72, No. 10, (October 1989), pp. 2771-2776, ISSN 0022-0302 
Sharma, B. K. \& Erdman, R. A. (1989b). Effects of dietary and abomasally infused choline on milk production responses of lactating dairy cows. Journal of Nutrition, Vol. 119, No. 2, (February 1989), pp. 248-254, ISSN 0022-3166

Snoswell, A. M. \& Xue, G. P. (1987). Methyl group metabolism in sheep. Comparative Biochemistry and Physiology Part B: Comparative Biochemistry, Vol. 88, No. 2, pp. 383-394, ISSN 1096-4959

Stipanuk, M. H. (1986). Metabolism of sulfur-containing amino acids. Annual Reviews Nutrition, Vol. 6, pp. 179-209, ISSN 0199-9885

Ueland, P.M. (2011). Choline and betaine in health and disease. Journal of Inherited Metabolic Disease, Vol. 34, No.1 , (February 2011), pp. 3-15, ISSN 0141-8955

Vuuren, A. M.; van Goselink, R. M. A., Zom, R., Veth, M. J. de, Baal, J. van (2010). Effect of rumen-protected choline on performance and hepatic triacylglycerol concentrations in early-lactating dairy cattle. In: Energy and protein metabolism and nutrition, G.M. Crovetto (Ed.), pp. 493-494, Wageningen Academic Publishers (EAAP publication $\mathrm{N}^{\circ} 127$ ) ISBN978-90-8686-153-8, Wageningen, The Netherlands.

Whitehead, C. C. \& Portsmouth, J. I (1989). Vitamin requirements and allowances for poultry. In: Recent Advances in Animal Nutrition, Haresign, W. \& Cole D. A. J., (Ed.), 3586, Butterworths, ISBN 0-407-01165X, London, UK.

Xu, G.; Ye, J., Liu, J. \& Yu, Y. (2006). Effect of rumen-protected choline addition on milk performance and blood metabolic parameters in transition dairy cows. Asian-Australasian Journal of Animal Sciences, Vol. 19, No. 3, pp. 390-395, ISSN 10112367

Xue, G. P. \& Snoswell, A. M. (1985). Regulation of methyl group metabolism in lactating ewes. Biochemistry International, Vol. 11, No. 3, (September 1989), pp. 381-385, ISSN 0158-5231

Zahra, L.C.; Duffield, T.F., Leslie, K.E., Overton, T.R., Putnam, D. \& LeBlanc, S.J. (2006). Effects of Rumen-Protected Choline and Monensin on Milk Production and Metabolism of Periparturient Dairy Cows. Journal Dairy Science, Vol. 89, No. 12, (December 2006), pp. 4808-4818, ISSN 1811-9743

Zeisel, S. H. (1988). "Vitamin-like" molecules. In: Modern Nutrition and Health and Disease, Shils M. \& Young V., (Ed.), 440-452, ISBN-10 0781741335, Philadelphia: Lea \& Febiger.

Zeisel, S. H. (1992). Choline: an important nutrient in brain development, liver function and carcinogenesis. Journal American College of Nutrition, Vol. 11, No. 5, pp. 473-481, ISSN 0731-5724

Zeisel S. H., \& Da Costa K. A. (2009). Choline: An Essential Nutrient for Public Health. Nutrition Reviews, Vol. 67, No. 11, (November 2009), pp. 615-623, ISSN 00296643

Zeisel, S.H.; Da Costa, K.A., Franklin, P.D., Alexander, E.A., Lamont, J.T, Sheard, N.F., and A. Beiser Choline, an essential nutrient for humans. The FASEB Journal, Vol. 5, pp. 20932098, ISSN 0892-6638 
Zeisel, S. H.; Mar, M., Zhou, Z. \& Da Costa, K. A. (1995). Pregnancy and lactation are associated with diminished concentrations of choline and its metabolites in rat liver. Journal of Nutrition, Vol. 125, No. 12, pp. 3049-3054, ISSN 0022-3166 